ThufuLA: Jurnal Inovasi Pendidikan Guru Raudhatul Athfal

Volume 9 issue 1, 2021

DOI: $10.21043 /$ thufula.v9i1.8781

\title{
Improving Children Verbal Language Competence Through Story Telling Used Visual Audio Media
}

\section{Ratno}

Ivet University, Semarang, Indonesia ratno.aha@gmail.com

\section{Dyah Kusbiantari}

Ivet University, Semarang, Indonesia dyahkusbiantari@gmail.com

Abstract: The Goal is to describe storytelling method through visual audio to improve verbal language competence and to know the result of using storytelling method through visual audio media. This study applied an action research with two variables, verbal language competence and storytelling with audio-visual media. The steps used were: Planning. Acting, Observing, and Reflecting. The subject was children of PAUD Alam Jungle School Consisted of 13 girls and 7 boys. The result showed that storytelling through visual audio media contributes significantly to the children' verbal communication improvement. It can be seen from the cycle I reach $50 \%$ (10 children) in category undeveloped, starting develop is $40 \%$ (8 children), and $10 \%$ (2 children) in category undeveloped. The cycle II showed that children on category developed properly are $85 \%$ (17 children) and category starting develops is $15 \%$ (3 children).

Keywords: Verbal Language, Storytelling, Visual Audio

Abstrak: Tujuan Penelitian ini adalah menjelaskan penerapan metode bercerita dengan media audio visual untuk meningkatkan kemampuan berbahasa verbal anak, dan mengetahui hasil dari penerapan metode bercerita menggunakan media audio visual. Jenis penelitian ini yakni Penelitian Tindakan Kelas (PTK) dengan menerapkan dua variabel yakni 
kemampuan berbahasa verbal dan metode bercerita melalui media audio visual. Tahapannya meliputi perencanaan (planning), tindakan (acting), observasi (observasing) dan refleksi (reflecting). Subyek yang diteliti adalah anak PAUD Alam Jungle School, terdiri dari 13 anak perempuan dan 7 anak laki-laki. Hasil penelitian ini menunjukan peningkatan secara siginifikan dari siklus I ke siklus II. Hasil siklus I, anak dengan kategori berkembang sesuai harapan $50 \%$ (10 anak), mulai berkembang $40 \%$ (8 anak), belum berkembang $10 \%$ (2 anak), sedangkan pada siklus II, anak dengan kategori berkembang sesuai harapan $85 \%$ (17 anak) dan mulai berkembang $15 \%$ (3 anak).

Kata kunci: Bahasa verbal, Bercerita, Audio Visual

\section{A. Introduction}

According to Anggraini \& Putri (2019) mentioned that goverment today are concern about Early Childhood Education and the society also aware how important is Early Childhood Education to develop children competence aspect. Children in this period is called the golden age, it means they will learn everything in their surrounding as their experience. They will get some experiences from their environments. The task of parents or adults is facilitating them with more stimulants in order they getting mature in preparing their self-confidence and independence. In the golden age, the development aspects grow rapidly. All components included character, and attitude is formed through their experiences. Most of children like doing some activities such as attention of their environment, imitating, touching and sensing. According to Hania \& Windiarti (2016) mentioned that the cerebellum (brain small ) included the brain part that conect the ability speaking, attention, the capacity to think, memory, and the sensory activity. Children need good environment with giving those stimulants in order to get more experiences. One of the important aspects in this period is verbal communication competence. Story telling is one of method in developing verbal communication competence. By story tell, children will have a chance to express their experiences. Story telling is a skill in telling that an event done. So through storytelling, the children can take many advantages and 
experiences in expressing their will, and also can improve the verbal communication competence. Audio visual media is one type of learning style media that used in teaching process.

According to Nurani, Pratiwi, \& Kusumaningtyas (2018) stated that Video is one type of audio-visual media that describe an object that moves together with sound natural or appropriate sound. Video capabilities depict live images the sound provides its own charm. Videos can provide information, expose the process, explain complex concepts, teach skills, shorten or extend time, and influence attitudes. Based on the real condition before applying story telling through audio visual, most of children were in low capability on language competence. They are not active in giving respond verbally. Some children prefer to keep silent during the meeting; sometimes they give simple respond to the teacher questions or instructions. By Applying audio visual media is expected that could improve verbal communication competence. So the children could express their will or to reject other' will and explain their opinion used verbal language. In this study, the researcher presents two problems concerning the use of storytelling to improve verbal language competence. These two problems are: (a) How to improve the children' language verbal competence through storytelling used visual audio media? (b) How the teaching of storytelling through visual audio media contributes to the children improvement in verbal language competence? The goals of this study are as follows: (a) To explain to what extent the use of storytelling with visual - audio media can improve children' verbal language competence. (b) To know the use of storytelling with visual audio media contributes to the children's improvement in verbal language competence. Significance of the study is giving information to enrich knowledge about teaching in the kindergarten. It also gives references about the use of storytelling method with visual - audio media to improve children' verbal language competence. Hopefully, most parents or adults understand that verbal communication is needed by the children for having relationship in their social life. For Teachers, hopefully, it can be references how to treat and teach their student in order to improve the verbal language competence. It is crucial for the children to express their will and idea by using verbal language. For researchers, it can be expected become worthy experience to do teaching learning 
process on improving verbal language competence to the children in kindergarten. It is an important references for another researcher to learn new knowledge about teaching used audio visual media.

Here were some previous researches related to language development for children as follows; Based on the journal of Anggalia \& Karmila (2014) who did research with the title is effort to improve the children language expression through hand puppet Muca (Moving mouth puppet) on group A TK Kemala Bhayangkari 01 Semarang. They applied a classroom action. The research was also conducted in two cycles. Research subjects expressive language skills are $\mathrm{A} 2$ group of kindergarten students Kemala Bhayangkari 01 Semarang as many as 23 children. The results showed an increase in the achievement of performance indicators on the condition prasiklus at $13.0 \%$, reaching $65.2 \%$ first cycle and the second cycle reaches $91.3 \%$. Marputri, Fakhriah, \& Dewi (2016) on journal entitle improving the children language competence through storytelling in PAUD Nurul Hidayah Aceh Besar. This research aimed to improve the children language competence. This research applied classroom action research with the subject is children in PAUD Nurul Hidayah Aceh Besar focus on children 5-6 year old. The total number of population is 10 children which consisted 5 boys and 5 girls. The data collection done through observation and assessment record (portfolio). This research is done through two cycles which consisted of three section in each cycle. The result of this research showed that through story telling has positive influence on improving the children language competence. It can be seen the final result of second cycle is 8 children who are active and 2 children are not active yet. Amalia (2018) on journal entitled teaching English with storytelling method in early childhood education teachers. Explained that the importance of English has an impact on the needs of future generations to learn English from an early age especially in Early Childhood Education and vocabulary is an important component that can support the mastery of all four language skills. Facing the difficulty of learning vocabulary, a method that is appropriate for the age of child development is needed. One of methods that could be used is storytelling. The research method used in this research is qualitative descriptive. The sample in this study was six early childhood education teachers 
in Sukabumi. Data collecting techniques were presentations and questionnaires. The presentations were held twice, in front of peers of early childhood education teachers and in front of students of early childhood education. After presentation, the questionnaires were conducted related to the implementation of the story telling method to the teacher. Based on the data collected, Teaching English with Story Telling Method give a good response with indicators shows that the content of the story, the properties used, the variety of vocabulary taught, moral values based on the stories and the ability of delivering the English vocabulary were good and suitable with the age of early childhood education.

\section{B. Discussion}

\section{Review of Literatures}

According to Campbell (Madyawati, 2016) person with language inelegancy is a competence in arranging words for conveying thinking, feeling and willing in order to be understood. Language is symbol that used as tool of communication by the society in order to work together, to have interaction, and self-identification. It is crucial to know the ways in which language functions for the early children in order to convince what they achieves by using language and to find out what meaning they attach to their experiences. Three year old children used language to find whether existing classifications near them. One example of classification is aimed to see the language used by three year olds from different groups. Improving language competences is one of absolute need for children to get success in their life and their social beings. As learners, most people try to performance with a clear and valid definition. Language related with a lot of things, as follows: (1) Language is consisted of words which compound into sentences. (2) Language has function for speaking, reading and writing. (3) There are a lot of variety languages typically related with different countries and societies. Discussing about the concept of language, it involved some elements of language itself. For example, the same word or diction can be used in different context. It depends on the purpose of the sentence. The word will have different meaning based on tone of accent, voice, or idea when someone speaking. Children usually will produce 
words by imitating the adult close to them. So, it is very necessary for the adult to use good diction and syntax role as a model for children to have a good style and manner in speaking. The language function for early childhood is as tool to develop intelligence and basic competence. According to Castello (Rakhmawati, Hasibuan, \& Reza, 2018) mentioned that language is a means to convey ideas from one thought to another that makes acquiring language as one of the most interesting aspects to observe. In addition, Nurbiana Dhieni (Nirwana, Mappapoleonro, \& Chairunnisa, 2018) stated that language development of children, especially for 3 to 5 years old children, is where they can speak well. At this age children are able to compose simple sentences and start to enjoy listening to simple stories and start talking a lot. Here can be noted that children stage development consist of pre lingual (0-1 year) where the children cannot say understanding word. They only say babbling, unclear sound language to convey feeling or sensing. This lingual period, most children star to pronounce some unclear words. Here, most of children usually uses non-verbal language to have communication mostly gestures to communicate or giving respond. Crying is the first language used for a new born baby to convey a will. Baby about 1-5 months old will show different tones of crying to indicate their emotions and feeling of sense. Next, Infants also begin laughing at this period. Infants in around 6-7 month old, they will use gesture to give any respond. They use crying as a sign to convey a will as tool of communication. It happens to baby on age 1-5 month old started to produce different tone of crying to express their emotion and feeling. On the next steps, they also try to imitate their mother, father, or adult about the tone. Baby in age 6-7 month old, they try to give any respond to their own name. Baby in age 10-12 month usually begins to use verbal communication. They will imitate word by word, sound, tone according to their environment condition. It means that their cognitive related to the communication ability has developed. They also use gesture to express their feeling and mood. This condition will not developed significantly if their parents, do not give any support in the form of communication intensively.

Non-verbal communication started with the intensive of parents or adults on implementing it in conversation. Babies are able to understand what parents are communicating to them. 
Infants in age 12 month old are usually less sensitive to understand phoneme change without any picture until they reach 14-17 months. Children in period 2-3 year old is in crucial period on getting ability in communication. They usually try to babbling; pronounce some words based on what they see. This period, children will create a meaningful simple structure to make communication easier. It needs patience, kindness, and respect when they imitate words from parents or adults. Children during this period begin to understand awareness as a factor in communication along with their growth of symbolic direction of language. Children in period 3-5 years of age are also recognizing about abstract thoughts and are still talking about concrete. Children start to try to be smooth in arranging sounds, syllables, and linking words in one thought. They involve participating in any conversations. At the moment of this stage toddlers still get difficulty to use verb tenses. They spend much time to understand functional words, pronouns, and auxiliary verbs. Otto (Pusari \& Karmila, (2018) mentioned that the level of language competence of early age children between 5 to 7 years old are able to speak up around 5 to 6 word in a sentence, the vocabulary is closed to 2000 , are able to explain thing used and tell what and how something are made from, know the relation of room and place, know their address, know nominal of money, count ten things, ask an information, differentiate their left and right using their own hands, know the general differences like big and small, know the equal and difference and can use all types of sentence, such as invitation, command, interrogative sentences and direct sentences.

Language competences are important for children to have communication. These competences will support children to have relationship with others and acquire from their surroundings including in the classroom. Language competences are about children acquiring and experiencing the rules for words compounding in sentences. It will express their idea, thoughts and feelings and understand the meaning of both spoken and written. The first five years period for children are hard and crucial moment in language development. During this point, new nerve cells will develop and connect in the brain that support the child to use language for self-expression. It will be the hardest one for them because as starting point before they got fluent in communication. Indarwati \& Diana (2017) stated 
that by using learning model method, and direct practice will give more experience for learning. By direct practice, children not only learn to find something, but also have the skill to analyze what they found and this skill can be gained only when they interact with their environments. Method is a part of learning strategy to find the goal of teaching-learning. There are a lot of methods can be used in teaching process, but not all strategy can be applied in the classroom. Teacher should choose the best method to convey the material prepared, so the teacher should pay attention through the material and characteristic children. In the kindergarten teaching learning process mostly related to Montessori Method. Montessori believed that children can develop and learn best in their environment set. The prepared environment set them easier to get experience and enjoy full for children in an orderly format. Classrooms Montessori is prepared for educators to share about childcentered education and active learning. Flexibility is the crucial characteristic of the prepared environment. Children in this center are free to explore materials based on their own choice, they learn what they find there. Maria Montessori was a master at creating environments for children that facilitated them to be independent, active, and learn. Montessori (2015) mentioned Auto education is the concept of children on capable of serving themselves. Children are supposed to be active involved in a prepared environment and they can choose any kind of activity, also choose literally educate themselves. Teachers should prepare classrooms with the purpose to educate the children become independence. The Teacher's Role focused on guiding the children with many activities without forcing them to complete all material prepared. They may be always ready to supply the desired help, but may never be the obstacle between the child and his experience" In general for strategy that used in teaching learning in kindergarten included playing, singing, and storytelling. The function of the method is one of tool to get the goal of teaching learning process. So, it can be concluded that the first step in determine what kind of the appropriate method is knowing and understanding the goal of the lesson, activity prepared. According to Madyawati ( 2016) storytelling is the conveying of events in words, and images often by improvisation or embellishment. Stories or narratives have been shared in every culture as a means of entertainments, 
educations, cultural preservation, and in stilling moral value. In conveying storytelling, it is needed media in order to make interest for shildren. According to Clark, Yates, Early, \& Moulton (Mellisa \& Yanda, 2019) there are several factors contributed in the ineffectiveness of media learning which means that the improvement of learning media need to be done. One of the learning media is audio-visual media which is believed to be able to increase the students' interest on their lectures. It is also an alternative means of conducting technology-based learning processes as its role in optimizing learning process. Hartono, Santoso, Raya, \& Yulianto (2016) added that by using computer technology, audio-visual content as adjusted according to the children's favorite colors, images, song tempo, and animation support. Audio-visual media is expected to present more interesting learning content in eeducational games. Some educational games are displayed in Figure.

\section{Research Method}

I intended to apply action research because it is a kind of research used in this study and I hoped it could help the children to develop verbal language competence. Action research was considered as a kind of research which is becoming significant in language education. This research has been applied in a number of different ways. This action research used two cycles included the first cycle and the second cycle. The first cycle consisted of: (1) planning, (2) acting, (3) observing, and (4) reflecting. The second cycle is followed up from the first cycle after conducting evaluation. The second cycle is revising the mistake made through the same steps as follows: (1) planning, (2) acting, (3) observing, and (4) reflecting. The researched applied action research to prove the effective of using audio visual media through story telling for improving children verbal language competence.

\section{a. Subject of the Research}

I chose the sources of the data or the subjects of the researchthat is the kindergarten children of Jungle School Semarang in the academic year of 2019/2020. The data that I obtain are the children mastery verbal language competence. In this study, a group of people taken as the population was kindergarten children. It will be a sampling research since I do not take all the members of the population as the subject of the 
research. Then, I will generalize the result of the research. The degree to which the selected samples represented the population is the degree to which the results are generalized. Considering time, fund and energy, it is more effective to use sample since the population of the study is relatively large.

b. Research Variable

Arikunto (2014) mentioned that research variable is an object of research or the main point from the research. Variable is anything that used by researcher in order to get any information about the action, and it will be seen as conclusion. Based on those explanation, the research can be identified as some variable consisted of dependent variable and independent variable. The dependent variable of this study is the verbal language competence and the independent variable is story telling method through visual audio media.

c. Assessment Indicator

The tool of data collection used in this study is a sheet of observation or assessment indicator that used by the teachers and observer. The function is to give assessment and as tool of observation as follows;

Table 1. Children Indicator Asessment

\begin{tabular}{clll}
\hline No & Variables & Indicator & Main Aspect \\
\hline \multirow{2}{*}{ 1. } & $\begin{array}{l}\text { Language } \\
\text { Competence }\end{array}$ & $\begin{array}{l}\text { Verbal } \\
\text { Language }\end{array}$ & $\begin{array}{l}\text { 1. Able to ask } \\
\text { question }\end{array}$ \\
\hline \multirow{2}{*}{2.} & $\begin{array}{l}\text { Language } \\
\text { Competence }\end{array}$ & $\begin{array}{l}\text { Verbal } \\
\text { Language }\end{array}$ & $\begin{array}{l}\text { 2. Respond to } \\
\text { question }\end{array}$ \\
\hline \multirow{2}{*}{3.} & $\begin{array}{l}\text { Language } \\
\text { Competence }\end{array}$ & $\begin{array}{l}\text { Verbal } \\
\text { Language }\end{array}$ & $\begin{array}{l}\text { 3. Verbal } \\
\text { communiction }\end{array}$ \\
\hline \multirow{2}{*}{4.} & Language & Verbal & 4. Retelling what \\
& Competence & Language & have seen \\
\hline
\end{tabular}

d. Research Procedure

This research is classical collaborative research which basically focused on conditional, contextual, and practical based on the problem appears in the daily teaching-learning activities of Jungle School. The activity research is preceded by observing previous cycle condition happened facing by children in jungle school, finding the problems focused on verbal language development, and trying to find solution for children in jungle school. The steps took in this study by designing and planning 
on the first cycle with some teachers of jungle school, applying the method and media prepared, observing the teachinglearning activity involving the head master of jungle school, and reflecting the results. Based on the result and observation, the next step done is planning in the second cycle as revising the activity on the first cycle. The next step chosen is just revising and observing what had done in the previous cycle.

1) First Cycle

In the first cycle, the researcher and observer did sharing and discussing about scenario of teaching-learning process. The activity prepared as follows:

1. 1 Make daily activity planning based on syllabus collaborated with teachers of jungle school.

1. 2 Planning and preparing the materials together with the teachers.

1. 3 Preparing observation sheet involving the headmaster of jungle school.

1. 4 Preparing children work sheet with shadow teacher of jungle school.

2) Second Cycle

Teacher and researcher discussed about teaching quality revision based on the reflection on the first cycle which attached in the form of teachers' note consisting the strength and the weakness of teaching-learning process in the first cycle. It is referred to the result of the first cycle that showed Teacher did some steps to cover the weaknesses of teaching-learning process as follows:

1. 1 Teacher will remind the children who are not active or unfocused during the teaching - learning process mainly for who sit in the back row.

1. 2 Teacher will revise and innovate the visual audio to be more attractive for the children.

3) Data Analysis

Based on the result of observation on the previous condition, the teacher and researcher try to make elaboration and innovation of teaching - learning process to improve the verbal language competence on the Kindergarten children of Jungle School Semarang. It is done by applying storytelling method through visual-audio media to take interest of children in improve verbal communications.

Assessment standard used in this research is as follows: 
1 = Developed well (Children can do the task independently and perfect)

$2=$ Developed properly (Children can do the task independently)

3 = Started develop (Children do the task need help from the teacher)

4 = Undeveloped (Children do not understand about the task)

Table 2 . The result of the first cycle

\begin{tabular}{|c|c|c|c|c|c|}
\hline \multirow{3}{*}{ No } & \multirow{3}{*}{ Research Subject } & \multicolumn{4}{|c|}{ Score } \\
\hline & & 1 & 2 & 3 & 4 \\
\hline & & DW & DP & SD & UD \\
\hline 1. & Aryasutta Deywa Brata & & $V$ & & \\
\hline 2. & Danish Rizki Siswanto & & & $V$ & \\
\hline 3. & Laurensia Grasia Violeta & & & & V \\
\hline 4. & Abrizam Hafsya Wicaksono & & & & $V$ \\
\hline 5 & Muh. Genius Arkantama & & & & $V$ \\
\hline 6 & Raihannun El Kiyora & & & & $V$ \\
\hline 7 & Najma Aleena Hakim & & & $V$ & \\
\hline 8 & Marsya Ghitsa Nabila & & & $V$ & \\
\hline 9 & Alena Benazir Nuria Agustin & & & & $V$ \\
\hline 10 & Salwa Aisyah & & & $V$ & \\
\hline 11 & Alby Khalfani Najmi & & & $V$ & \\
\hline 12 & $\begin{array}{l}\text { Muhammad Arkana } \\
\text { Ghaitsani }\end{array}$ & & & & $V$ \\
\hline 13 & Adiba Shakila Atmarini & & & $V$ & \\
\hline 14 & Zaydan Ali & & $V$ & & \\
\hline 15 & Syafiya Aulia Rahma & & & $V$ & \\
\hline 16 & Naura & & & & $V$ \\
\hline 17 & Happy Kanaya Setiawan & & & & $V$ \\
\hline 18 & Rachel & & & & $V$ \\
\hline 19 & Muhammad attariz & & & $V$ & \\
\hline 20 & Syakira Mili Carina & & & & V \\
\hline & Total Number & 0 & 2 & 8 & 10 \\
\hline
\end{tabular}

The percentage standard criteria on the first cycle is as follows.

Percentage $=\frac{\sum \text { ChildrenDP }}{\sum \text { Children }} \times 100$ 


$$
=10 \%=\frac{2}{20} \times 100 \%
$$

Based on the result of the cycle I, it can be explained that 50 $\%$ (10 children) was in category undeveloped, starting develop was $40 \%$ (8 children), and $10 \%$ ( 2 children) was in category undeveloped. Here, the researcher continue applied the storrytelling used audio visual media and it had been discussed with the collaborator in order to find out problem faced during teaching-learning process. The researcher did reviewing and reflecting before continue to the second cycle. Some revision had been done and the researcher made lesson planned for applied in the second cycle.

\begin{tabular}{|c|c|c|c|c|c|}
\hline \multirow[t]{2}{*}{ No } & \multirow[t]{2}{*}{ Research Subject } & 1 & 2 & 3 & 4 \\
\hline & & DW & DP & SD & UD \\
\hline 1. & Aryasutta Deywa Brata & & $V$ & & \\
\hline 2. & Danish Rizki Siswanto & & $v$ & & \\
\hline 3. & Laurensia Grasia Violeta & & $v$ & & \\
\hline 4. & Abrizam Hafsya Wicaksono & & $V$ & & \\
\hline 5 & Muh. Genius Arkantama & & $v$ & & \\
\hline 6 & Raihannun El Kiyora & & & $v$ & \\
\hline 7 & Najma Aleena Hakim & & $V$ & & \\
\hline 8 & Marsya Ghitsa Nabila & & $V$ & & \\
\hline 9 & Alena Benazir Nuria Agustin & & & $v$ & \\
\hline 10 & Salwa Aisyah & & $v$ & & \\
\hline 11 & Alby Khalfani Najmi & & $V$ & & \\
\hline 12 & Muhammad Arkana Ghaitsani & & $V$ & & \\
\hline 13 & Adiba Shakila Atmarini & & $V$ & & \\
\hline 14 & Zaydan Ali & & $V$ & & \\
\hline 15 & Syafiya Aulia Rahma & & $v$ & & \\
\hline 16 & Naura & & $v$ & & \\
\hline 17 & Happy Kanaya Setiawan & & $V$ & & \\
\hline 18 & Rachel & & $v$ & & \\
\hline 19 & Muhammad attariz & & $V$ & & \\
\hline 20 & Syakira Mili Carina & & & $V$ & \\
\hline
\end{tabular}

Tabel 3. The result of the first cycle 


\begin{tabular}{ccccc}
\hline Total Number & 0 & 0 & 17 & 3 \\
\hline
\end{tabular}

The percentage standard criteria on the second cycle is as follows.

Percentage

$$
\begin{aligned}
& \frac{\sum \text { ChildrenDP }}{\sum \text { Children }} x 100 \\
= & \frac{17}{20} \times 100 \% \\
= & 85 \%
\end{aligned}
$$

The cycle II showed that was a significance improvement on the result. It can be seen that children on category developed properly is $85 \%$ (17 children) and category starting develop is $15 \%$ ( 3 children). Storytelling used Visual Audio media is as tool of improving verbal communication language to the kindergarten children of jungle school Semarang. Visual audio is an interesting media applying to teaching and learning process. It is proved that this media is effective to improve the verbal language competence.

\section{Conclusion}

Based on the observation, analyses, and discussion conducted into two cycles, it can be concluded that 1) Applying the visual audio media can improve the children verbal language competence of Jungle school kindergarten. 2) The results showed that there is any improvement of the standard achievement criteria. It can be seen from the first cycle reach totally $50 \%$ (10 children) who were in category undeveloped. For category starting develop is $40 \%$ (8 children), and with category undeveloped reach $10 \%$ (2 children). The research conducted continually on the second cycle with the result showed that children on category developed properly is $85 \%$ (17 children) and the rest, children on category starting develop is $15 \%$ ( 3 children). Based on that result, it can be concluded that there was significant improvement on verbal language competence between the result of first cycle and the second cycle.

\section{References}

Amalia, A. R. (2018). Teaching English With Story Telling Method in Early Childhood Education Teachers. A Journal of 
Culture English Language Teaching Literature \& Linguistics, 5(2), 1-7. https://doi.org/10.22219/celticumm.vol5.no2.17

Anggalia, A., \& Karmila, M. (2014). Upaya Meningkatkan Kemampuan Bahasa Ekspresif Anak Dengan Menggunakan Media Boneka Tangan MUCA (Moving Mouth Puppet) Pada Kelompok A TK Kemala Bhayangkari 01 Semarang. Jurnal Penelitian PAUDIA, $3(2)$,

133-159. https://doi.org/https://doi.org/10.26877/paudia.v3i2\%20 Oktober.509

Anggraini, W., \& Putri, A. D. (2019). Penerapan Metode Bermain Peran (Role Playing) dalam Mengembangkan Kognitif Anak Usia 5-6 Tahun Wardah Anggraini 1, Anggi Darma Putri 2. Journal of Early Childhood Education and Development, 1(2), 104-114. https://doi.org/10.15642/jeced.v1i2.466

Arikunto, S. (2014). Prosedur Penelitian, Suatu Pendekatan Praktek (Cet. 14). Jakarta: Rineka Cipta.

Hania, D. A., \& Windiarti, R. (2016). Indonesian Journal of Early Childhood 3D Puzzle: As a Fine Motor Skill Therapy Media for Children with Autistic Syndrome. Indonesian Journal of Early Childhood Education Studies, 5(1), 59-67. https://doi.org/10.15294/ijeces.v5i1.11278

Hartono, M., Santoso, A. G., Raya, C. L., \& Yulianto, B. (2016). Audio Visual Media Component In Educational Game For Elementary Students. COMTECH: COMPUTER, MATHEMATICS AND ENGINEERING APPLICATIONS, 7(4), 255-265.

https://doi.org/https://doi.org/10.21512/comtech.v7i4.25 15

Indarwati, I., \& Diana, D. (2017). Indonesian Journal of Early Childhood The Effectiveness of Manipulative Scales Media in Children 's Group B Measurement Concept Ability at Tk Negeri Pembina Sragen. Indonesian Journal of Early Childhood Education Studies, 6(1), 48-53. https://doi.org/10.15294/ijeces.v6i1.15788

Madyawati, L. (2016). Strategi Pengembangan Bahasa Pada Anak. Jakarta: Prenadamedia Group.

Marputri, R., Fakhriah, F., \& Dewi, F. (2016). Meningkatkan Kemampuan Bahasa Anak Melalui Kegiatan Bercerita Di PAUD Nurul Hidayah Aceh Bessar. Jurnal Ilmiah Mahasiswa Pendidikan Anak Usia Dini, 1(1), 86-92. Retrieved from 
http://jim.unsyiah.ac.id/paud/article/view/424

Mellisa, M., \& Yanda, Y. D. (2019). Developing audio-visual learning media based on video documentary on tissue culture explant of Dendrobium bigibbum. JPBI (Jurnal Pendidikan Biologi Indonesia), 5(3), 379-386. https://doi.org/10.22219/jpbi.v5i3.9993

Montessori, M. (2015). Metode Montessori (Panduan Guru dan Oang Tua Didik PAUD). Jogjakarta: PUSTAKA PELAJAR.

Nirwana, N., Mappapoleonro, A. M., \& Chairunnisa, C. (2018). Indonesian Journal of Early Childhood The Effect of Gadget Toward Early Childhood Speaking Ability. Indonesian Journal of Early Childhood Education Studies, 7(2), 85-90. https://doi.org/10.15294/IJECES.V7I2.28548

Nurani, Y., Pratiwi, N., \& Kusumaningtyas, N. (2018). The Use of Smartphones as Self Assessment for Teaching Skills. Indonesian Journal of Early Childhood Education Studies, $7(2)$, 141-143.

https://doi.org/10.15294/IJECES.V7I2.28589

Pusari, R. W., \& Karmila, M. (2018). Indonesian Journal of Early Childhood The Effectivity of Language Games Method and Learning Motivation Toward the. Indonesian Journal of Early Childhood Education Studies, 7(1), 46-52. https://doi.org/10.15294/ijeces.v7i1.10179

Rakhmawati, N. I. S., Hasibuan, R., \& Reza, M. (2018).

Indonesian Journal of Early Childhood Using Multisensory on the Ability to Recognize Letter Sounds and Forms of. Indonesian Journal of Early Childhood Education Studies, 7(2), 111-116.

https://doi.org/10.15294/IJECES.V7I2.28554 